\title{
The 16th International
}

Conference on the History of Concepts

\section{PROCEEDINGS}

Bilbao, 29-31 August 2013 


\title{
The 16th International Conference on the History of Concepts
}

\author{
Concepts on the Move
}

Cross-Cultural and Cross-Disciplinary Transfers, Entanglements, Receptions, Translations and Redefinitions in Conceptual History

Bilbao and San Millán de la Cogolla (La Rioja), 29-31 August 2013

DOI: http://dx.doi.org/10.1387/conf.hcg2013.2

\section{ORGANIZERS}

Grupo de Historia Intelectual de la Política Moderna - UPV

Universidad del País Vasco - Euskal Herriko Univertsitatea

Cilengua - Centro Internacional de Investigación de la Lengua Española

Iberconceptos - Proyecto y red de investigación en historia conceptual comparada del mundo iberoamericano

Contributions to the History of Concepts - HPSCG

\section{SPONSORS}

Ayuntamiento de Bilbao

Centro de Estudios Políticos y Constitucionales - Ministerio de la Presidencia

Universia- Banco Santander 


\section{Table of Contents}

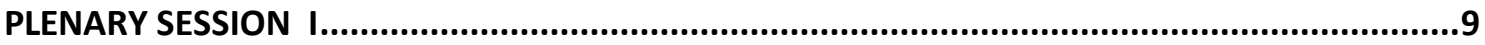

History: The Name and the Concept Yesterday and Today ............................................9

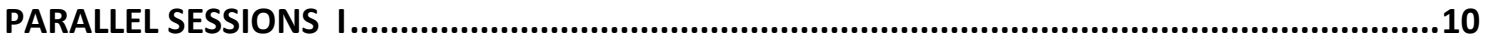

GROUP A Enlightenment and Historical Culture ..............................................................10

Enlightenment and Freemasonry. Hypothesis for a Post-koselleckian

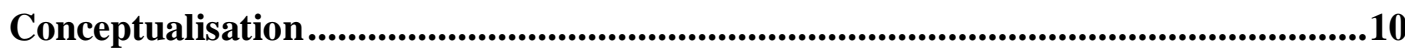

History of History at Present Time: Some Disciplinary and Professional Implications concerning the Concept of Historical Culture .........................................................26

Tracking "the Enlightenment" Across the Nineteenth Century ..................................30

GROUP B Ideologies and Political Concepts in the $20^{\text {th }}$ Century........................................39

What is Liberalism? Definitions, Approaches, Narratives..........................................39

Begriffsgeschichte and Hermeneutics: Reflections on the Theoretical Base of Conceptual History ...............................................................................................47

Fascismo y antifascismo durante la II República: una aproximación histórico-

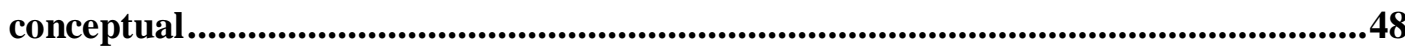

Conceptual Asymmetries in Totalitarian and Democratic Discourse: Leadership

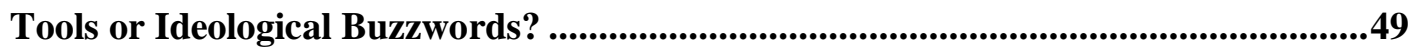

GROUP C Identidades y grupos étnicos en América Latina ....................................................51

Acerca del inventario conceptual de los hombres del orbe indiano de la época hispánica.

El movimiento indígena ecuatoriano y su discurso - Un análisis de discurso centrado en los conceptos ......................................................................................................................58

Los yoremes de Sinaloa y su inclusión a la sociedad de la información.......................65

Conceptos de la modernidad política en guaraní ......................................................66

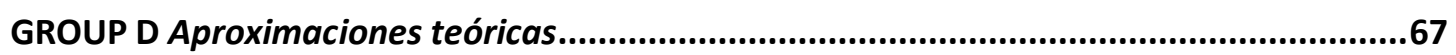

Notes from the Abyss: Rethinking Colonial and Postcolonial Historical Concepts ....67

El concepto de "concepto" en Qu'est-ce que la philosophie? de Gilles Deleuze ............79

Conceptos pedagógicos en la obras de John Dewey y Anton S. Makarenko: un acercamiento comparativo ......................................................................................................8

Conceptos más contextos. Algunos apuntes metodológicos sobre la relación entre memoria e historia conceptual 
Historia conceptual y Quentin Skinner: similitudes, tensiones y diferencias .

GROUP E Conceptos de la vida política en la modernidad hispana e hispanoamericana ....95

Traducción y transferencia cultural del krausismo: la figura de Julián Sanz del Río 95

El concepto conservador en la historia del México. Siglo XIX.

De la lucha revolucionaria a la unidad por las democracias: cambios semánticos del término propaganda, México, 1934-1942

Terrorismo católico: la imagen liberal del conservadurismo en Quito en la segunda

mitad del siglo XIX

PARALLEL SESSIONS II

GROUP A La temporalización en una era de revoluciones

La temporalización de los discursos políticos durante la independencia de Brasil (1820 - 1823)

Los momentos en el uso de "liberalismo" y "latinoamericanismo" en la obra del historiador uruguayo Arturo Ardao.

En espera de la `consumación de los siglos’. Temporalidad y escatología durante la era de las revoluciones.

Los conceptos del progreso: la generación de 1842 chilena entre la religión y la filosofía

GROUP B Literature and Postcolonial Tropes

The Norwegian auteur Concept

Tintin au Congo: Sovereignty, Alterity, Progress and Post-Colonial World

De la psiquiatria para la literatura en Portugal: el concepto de degeneración

GROUP C Pre-histories of Post-Communism.

Usages of the Concept of Totalitarianism among Dissident Intellectual Subcultures in Slovenia, 1950s - 1980s

Political Languages of Anti-Solidarity: Mirosław Dzielski and the Differentia Specifica of Polish Neo-Liberalism

Transformations of Feminism from Socialist Yugoslavia to Post-Socialist Hungary 163 GROUP D Conceptos de libertad y democracia en América Latina

Liberté d'enseignement / libertad de enseñanza en el siglo XIX: trayectorias, variaciones y transferencias conceptuales entre México, Francia y Colombia. 164

Libertad y autoridad. Religión y república en Chile a fines del siglo XIX .174

El concepto "democracia” en Iberoamérica durante el siglo XIX 183

GROUP E Conceptos fundamentales del mundo moderno 192

Maquiavelo: la invención política de lo humano .192

La voz filosofía en textos americanos del siglo XVIII. 200

Si no son conceptos, ¿qué son? El caso del humanitarismo 209

Mitos sobre la tolerancia 
PARALLEL SESSIONS III.

GROUP A Civilizing Emotion ...........................................................................226

Civilizing Emotion. Civility and Civilization in Europe and Asia ...........................226

GROUP B Theoretical Issues.......................................................................228

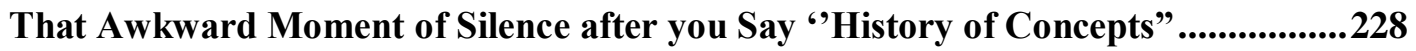

Between Koselleck and Nietzsche: Begriffsgeschichte, the Will to Power, and a New

Politics of Translation ....................................................................................................229

Disunified Semantics and the History of Concepts...............................................230

Old Europe in Ruins. Otto Brunner, Reinhart Koselleck and the Sattelzeit...............231

GROUP C Temporalidades y conceptualización ...........................................................2232

Tiempo de fantasmas. Anacronismos y supervivencias en la modernidad tardía .....232

Jacob Baegert y la condición temporal del Paraíso ....................................................242

Temporalidad y experiencia en la primera mitad del siglo XIX en España ..............243

GROUP D Conceptual Struggles and Challenges to Parliamentary Politics.......................250

Procedural Alternatives for Parliamentary Government. A Project Against the

Current in Westminster 1913-1914.......................................................................250

Conceptual and Rhetorical Struggles of Parliamentary Economic Policy Debates ..251

The Concept of Welfare State in Finnish Parliamentary Debate .............................252

Recasting Liberalism: Victorian 'Advanced' Liberals and Political Reform............253

Influencing the EU-regime by Parliamentary Politics: The Case of the EP.............254

GROUP E La concepción del oficial público en la historia .................................................260

La importancia de llamarse consejo. La creación de órganos administrativos durante el valimiento del conde-duque de Olivares y la relevancia de sus nominaciones.......260

The Judge in the Seventeenth Century: A Royal Official between Legislation, Doctrine and Case Law. The Sicilian Case 267

Representar el rey, «a imitación de las estrellas, las cuales en ausencia del sol lucen»: ser ministros idóneos en el Reino de Sicilia en el siglo XVII

Técnica, inamovilidad, incompatibilidad: el concepto del funcionario público y su fundamentación en la España de Entreguerras.

Las transformaciones de las dinámicas institucionales del siglo XX y el papel del juez constitucional como alto funcionario ...........................................................................281

PLENARY SESSION II ................................................................................................287

A. Issues and Problems in East Asian Conceptual History Research .....................287

B. Putting Concepts on Display: Reflections on Conceptual Performances ..............288

PLENARY SESSION III ........................................................................................289

Crisis de los conceptos modernos y renovación de los estudios históricos .................289

PARALLEL SESSIONS IV ............................................................................290 
GROUP A Global and Cosmopolitan Concepts

The Place of "New Cosmopolitanism" in Conceptual History ........................................290

"Human Rights" in Scandinavia after the Second World War .....................................300

The Concept of Manhood and the Formation of Modern Standard of Behavior .......306

GROUP B Images of Foreign People and National Concepts.

The Catholic King and the Ottoman Sultan. The Metaphor of the Turk in the

Transnational Discourse on the Crisis of the Spanish Monarchy in the Early

Nineteenth Century

Siberian Barbarians and Savages in the Concept of Russian Civilizing Mission .......315

Visions of the Incas, from Cameralists to Pre-Marxian Socialists ................................316

Portuguese and Barbarians.

Patria in the Vernacular: Finnish Intellectuals and the Concept of Fatherland in

Swedish and Russian Imperial Contexts, ca 1780-1830 ............................................319

GROUP C Science, Knowledge and Practice ..........................................................320

Conceptual Transformations in Psychiatry ...........................................................................320

Between Discipline and Propaganda - Why Historical Concepts of Medical

Practitioners Escape Academia, Inc.

A Case Study from the History of Science: Discussion on the Concept of

Incorporeality in the Middle of $17^{\text {th }}$-Century England ............................................334

From Common to Limited: The De-republicisation of the Corporation ......................335

GROUP D Metáforas y conceptos de lo social ................................................................336

El concepto de estado de naturaleza: cambios de significado y cambios de objeto ...336

El contrato social. Metáfora y concepto.......................................................................348

El concepto de ciencia(s) social(es) como construcción socio-histórica y como visión de

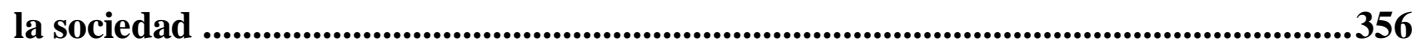

La transformación del papel de las metáforas del vínculo político y social en los siglos

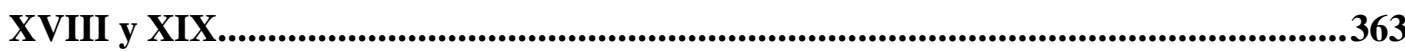

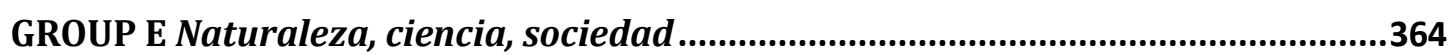

Metáforas y conceptos tecnológicos en los discursos de Joaquín Muñoz Delgado como defensa ante la Inquisición (1784-1791) ................................................................364

La construcción de la ciencia médica en Buenos Aires, 1820-1850..............................372

Praxis-speculatio: dos conceptos entre el pensamiento científico-matemático y su manifestación visual en el siglo XVII en el frontispicio del Mathesis Biceps de Juan

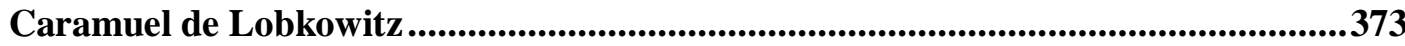

Polisemia del cólera: humor, patología, epidemia y furia popular en el Madrid de 1834.

La "economía verde" al servicio del capital. Un ensayo sobre la apropiación y neutralización discursiva de los términos ecologistas. 
PARALLEL SESSIONS V. 390

GROUP A Metaphors and Concepts .390

History of Concepts and Conceptual Metaphors 390

Masks: The Narrative of Identity and the Concept of "Person" 399

The Theatre Metaphor and the Concept of Representation .404

Concepts and Counter-concepts of Empire in the Process of "National Awakening" in Lithuania . 405

GROUP B Conceptos del poder imperial y post-imperial.

'Rey de España'. La calificación del monarca católico por sus aliados exteriores y la hegemonía española en los siglos XVI y XVII .

Orígenes y evolución del concepto de imperio en Hispania: el reino-imperio leonés (ss. X - XII).

El concepto colonia en el lenguaje de los operadores de la monarquía hispanoamericana del siglo XVIII

Poderes locales y control estatal. Apuntes sobre el ordenamiento territorial de la Provincia/Estado Oriental del Uruguay hasta mediados del siglo XIX

Omnia in verbis: el origen de la idea/metáfora del mundo como texto

De Oriente a Occidente. El juego del Go, un universo de conceptos y metáforas .

The Historical Novel and Historiography in Contemporary Spain: An Ethical Debate on Understandings of Memory and Identity

GROUP D Artes, iconografía y conceptos .

Imágenes y palabras con fuerza, o la política entra por todos los sentidos (Galicia, 1808-1868)

Apuntes para una historia conceptual del campo de la formación artística en México

Sobre héroes y pueblos. Notas sobre las formas de representar la participación política en la pintura histórica en el Uruguay (1850-1950)

GROUP E Repúblicas y republicanismo en Iberoamérica (I)

La Revolución Pernambucana de 1817.

Democracia latina y repúblicas latino-americanas: proyectos y contramodelos de los republicanos españoles decimonónicos

La república federal hispano-cubana: conceptos, lenguaje compartido y acción política republicana en Cuba y España a finales del siglo XIX.

PARALLEL SESSIONS VI.

GROUP A Borders, Territoriality and Nationality. 481

History Confronts Geography: The Case of Ukraine. 481 
Territoriality, State and Nationality in the Making of Borders of Finland: Finland in the Peace Treaties between Russia and Sweden 1323-1809 483

Shifting Hungarian Narratives on Europe, Nationality and Borders: the Political Language of Cross-border Cooperation .

Border Cases: Expelling Policy and "Nation" in 20th Century Finland and Denmark

Borders, Territoriality and Nationality in the Case of Denmark and Greenland .....495

GROUP B Rhetoric and Conceptual Change ...........................................................496

Hobbes, Civil Law, Liberty and The Elements of Law .............................................496

The Nouvelle Droite behind the True Finns Party's Xenophobic Discourse .............509

Contextualism and International Relations: The Turn to Rhetoric and Genealogy .517

Rhetoric and the Micro-politics of Conceptual Change in European Integration ....524

The Uses of Consensus in Spanish Parliamentary Politics: Outline for a Comparative

Study .........................................................................................................................................553

GROUP C Reception in/from Non-European Environments ..................................534

Discursive Unities to the Test of the Stranger: Reception Studies of Philosophical

Ideas in Turkey ...........................................................................................................................554

The Haitian Revolution and the Redefinition of Modern Citizenship within a

Republican Empire: A Comparative and Transnational Perspective, 1790s-1820s..536

The concept of sociability in Servando Teresa de Mier: A study of the translation of

Pufendorf's Natural Law theory in Italy and its reception in America....................545

GROUP D Conceptos de espacios post-imperiales....................................................546

El concepto de hispanidad en el pensamiento político colombiano $(1810$ - 2010).....546

Venezuela y la venezonalidad..................................................................................555

La percepción del Pacífico en las Relaciones Internacionales y la marginación de la Oceanía en la historiografía española: una apuesta por el concepto de la Hispano-

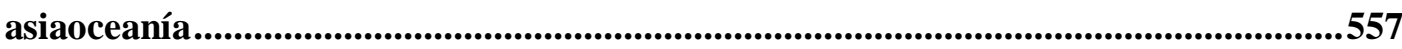

Reformulaciones de los conceptos de imperio e imperialismo en el marco de la globalización capitalista neoliberal ....................................................................................558

GROUP E Traducción de conceptos políticos y científicos entre Europa y América.566

La traducción de textos políticos en Hispanoamérica en la era de las revoluciones: puntos de partida para un abordaje conceptual.................................................566

De la "piedra del gallinazo" americana a la obsidiana europea: la (re)interpretación europea de una materia exótica (c. 1750 - 1799).

Mecanismos de la propaganda política de los porteños en la época de las Cortes de

Cádiz : discursos de Belgrano y Castelli dirigidos a los indios (1810-1813)

Estrategias argumentativas y retóricas en dos traducciones en lenguas indígenas de la Proclama a los habitantes de Ultramar (1812). 


\section{The Judge in the Seventeenth Century: A Royal Official between Legislation, Doctrine and Case Law. The Sicilian Case}

Francesco Di Chiara (fra.dichiara@virgilio.it)

\section{ABSTRACT/RESUMEN:}

A consolidated - even if outdated - legal-historical tradition defines under the generic name of "Grande Tribunale" (Supreme Court) the high Court of every stateorganization of the Modern period; a royal court composed only by the choicest jurists, personally appointed by the sovereign, with exclusive competence on a number of subjects (above all crimen laesae maiestatis) and competence of appeal on any sentence issued by lower tribunals.

Like all the others territorial-political systems in Europe, even Siciliy is characterized by the presence of these royal Courts of Appeal. Therefore, being so relevant the analysis of these structures, wich stood at the top of the administrative and jurisdictional organization of early modern kingdoms, equally valuable is the study of the officiales, i.e. the judges who formed the courts. These figures, in fact, constituted a powerful and often cohesive class, the so-called togati, which greatly influenced the institutional dynamics of the Five seventeenth century monarchies.

Appointed by the sovereigns in order to set up their own judicial arm and ensure the strict application of the royal law, these officials actually exercised an alternative power, often opposing to the central one. This counter-power stemmed precisely from the prominent role performed, ex officio, in the administration of justice of last degree, not to mention the personal prestige claimed by these judges, chosen among the most distinguished jurists of the realm and coming from the most relevant families.

A silent confrontation, then, that elects Law - and in particular the rules of the process - as a privileged ground of clash. This is a capital fact, especially if focusing, as I intend to do in this paper, on the collections of Seventeenth century decisiones relating to the judgements of the "Supremi Tribunali" of the Regnum Siciliae. These represent a literary genre flourishing in Sicily in that time, a genre to which the most distinguished jurists devoted themselves, the same who, as mentioned, were part of those same courts as judges. These primary sources return an image of a legal doctrine committed to provide such an extensive interpretation of the royal law as to result almost subversive, presenting a scheme in wich the doctrin produced by the togati became itself a source of law, thus overtaking the royal legitimacy.

Here, then, as the Sixteenth century judge, in his role as high royal official, becomes the balance of the political, institutional an doctrinal reality of the Regnum Siciliae. 


\section{TEXTO/TEXT:}

The purpose of the present contribution is to give an account of how a royal official as the judge in the Seventeenth century might influence the judicial practice applied in Regnum Siciliae both ex officio as a member of the Supreme Courts of the Kingdom that as a jurist author of works of doctrine especially collections of decisiones. An influence that is expressed in terms of application and interpretation of the law of the sovereign.

Like all the others modern territorial-political systems in Europe, even Siciliy is characterized by the presence of royal Courts of Appeal, institutions that a consolidated - even if outdated - legal-historical tradition brought together under the generic name of "Grandi Corti” (Great Courts) or "Tribunali Supremi " (Supreme Courts).

It is known that the definition of "Grande Tribunale" can be related to the Supreme Court of every state-organization of the modern period; a high court composed only by the choicest jurists, personally appointed by the sovereign, with exclusive competence on a number of subjects (above all crimen laesae maiestatis) and competence of appeal on any sentence issued by lower tribunals. In the past decades, the studies on the "Grandi Tribunali" had a significant development, even though characterized by sporadic occurrence; in addition, it's to point out that, at least by historians of law, it has been paid more attention to the production of case law - in particular the collections of decisiones - than to the procedural documentation. ${ }^{2}$

Therefore, being so relevant the analysis of these structures, wich stood at the top of the administrative and jurisdictional organization of early modern kingdoms, equally valuable is the study of the officiales, i.e. the judges who formed the courts. These figures, in fact, constituted a powerful and often cohesive class, the so-called togati, which greatly influenced the institutional dynamics of the sixteenth- seventeenth century monarchies.

\footnotetext{
${ }^{1}$ Is known that the issue was addressed around the 70s of the last century from studies by Gino Gorla, I Tribunali Supremi degli Stati italiani. fra i secc. XVI e XIX, quali fattori della unificazione del diritto nello Stato e della sua uniformazione fra Stati (Disegno storico-comparatistico), in La formazione storica del diritto moderno in Europa, I, Firenze 1977, pp.445-532; on conceptual and definitional problems posed by this historiographical category cf M. Ascheri, Tribunali Giuristi e Istituzioni dal medioevo all'età moderna, Bologna 1989; R. Savelli, Tribunali, "decisiones" e giuristi: una proposta di ritorno alle fonti, in Origini dello Stato. Processi di formazione statale in Italia fra medioevo ed età moderna, edited by G. Chittolini-A. Mohlo-P. Schiera, Bologna 1994, pp.397-421; I. Birocchi, Alla ricerca dell'ordine, Torino 2002, pp.85-93.

${ }^{2}$ The most significant examples are U. Petronio, Il Senato di Milano. Istituzioni giuridiche ed esercizio del potere nel Ducato di Milano da Carlo V a Giuseppe II, I, Milano 1977; Id., I Senati giudiziari, in Il Senato nella storia. Il Senato nel medioevo e nella prima età moderna, Roma 1997, pp.355-453; G.P. Massetto, Monarchia spagnola, Senato e Governatore: la questione delle grazie nel Ducato di Milano. Secoli XVI-XVII, in "Archivio storico lombardo", CXVI (1990), pp.75-112; M.N. Miletti, Stylus iudicandi. Le raccolte di "decisiones" del Regno di Napoli in età moderna, Napoli 1995; Grandi tribunali e rote nell'Italia di antico regime, edited by M. SbriccoliA. Bettoni, Milano 1993; J. Krynen, Qu'est-ce qu'un Parlement qui représente le roi?, in Excerptiones iuris: Studies in Honor of André Gouron, edited by B.Durand-L. Mayali, Berkeley 2000, pp.353-66.
} 
Appointed by the sovereigns in order to set up their own judicial arm and ensure the strict application of the royal law, these officials actually exercised an alternative power, often opposing to the central one. This counter-power stemmed precisely from the prominent role performed, ex officio, in the administration of justice of last degree, not to mention the personal prestige claimed by these judges, chosen among the most distinguished jurists of the realm and coming from the most relevant families.

A silent confrontation, then, that elects Law - and in particular the rules of the process - as a privileged ground of clash. This is a capital fact, especially if focusing, as I intend to do in this paper, on the collections of Seventeenth century decisiones relating to the judgements of the "Supremi Tribunali" of the Regnum Siciliae.

Referring to case law in late-medieval and early-modern European law, particularly in the ius commune tradition, usually means relying on collections of socalled Decisiones or continental-type law reports, which were works written by authors in their private capacity, and therefore works which belonged primarily to legal doctrine. These collections rarely reproduced the text of the judgements, which would anyway, as they did not express the legal principles upon which the judge or the court had relied, not have fulfilled the purpose of reporting decided cases. Most collections of Decisiones contain a legal analysis or commentary of one or more decisions from one or more courts. Because many of these printed collections would nonetheless purport to present the legal grounds and reasoning behind the decisions, they were instrumental, as a successful genre in early-modern legal literature, in establishing the notion that cases did contribute to legal developments, and could therefore qualify as an authority or a "source" of law, and therefore as "case law". 3

Legal science Sicily, between '500 and '600 is characterized by a very close connection with the field of procedure. This is evident, in fact, from the works of sicilian jurists which are composed in this period, at least from a purely quantitative point of view. A production which is so wide and varied in terms of expressing the legal doctrine of Siciliy between the fifteenth and seventeenth century is important from the point of view of quantity but especially valuable from that of quality, according to the high degree of authority both within the island and that which reached beyond the borders of it, evidenced especially by the spread of the largest collections of decisiones of the sicilian courts, which were printed in various editions across most of Europe.

The first collection of decisiones of a Sicilian court came out in 1593 and is assigned to the judge Francesco Milanese. ${ }^{4}$ The work opens, stating that this is a very fortunate series of Decisiones for Sicily. It is, in fact, followed by editions of many other books whose authors-Mastrillo, ${ }^{5}$ Intrigliolo, ${ }^{6}$ Del Castillo, ${ }^{7}$ Giurba, ${ }^{8}$ Muta, ${ }^{9}$ Caracciolo ${ }^{10}$

\footnotetext{
${ }^{3}$ A. Wijffels, Legal Records and Reports in the Great Council of Malines (15th to 18th Centuries), ), in Judicial records, law reports and the growth of the Case-law, edited by J.H.Baker, Berlin 1989, pp. 181-207.

${ }^{4}$ F. Milanese, Aureae decisiones Regiae Curiae Regni Siciliae, vol. I e II, Venetiis 1593.

${ }^{5}$ G. Mastrillo, Decisiones Consistorii Sacrae Regiae Conscientiae Regni Siciliae, Panormi 1606.

${ }^{6}$ N. Intrigliolo, Decisiones aureae Magnae Regiae Curiae Regni Siciliae, Panormi 1609.

${ }^{7}$ G.F. Del Castillo, Decisiones Tribunalis Consistorii Sacrae Regiae Conscientiae Regni Siciliae, Panormi 1613.

${ }^{8}$ M. Giurba, Decisiones novissimae Consistorii Sacrae Regiae Conscientiae Regni Siciliae, Messanae 1616.
} 
and Basilicò, ${ }^{11}$ to name the best-known representatives are the most influential among Sicilian lawyers and judges lived between the second half of the sixteenth and the seventeenth century. Their collections are inherent mainly to causes discussed in the courts of the Regia Gran Corte ${ }^{12}$ and of the Concistoro della Sacra Regia Coscienza, ${ }^{13}$ with no discernible collections of judgments of the Curia Rationum. Most of the decisiones regards the feudal matter, the most debated in local courts, although there are collections entirely focused on criminal disputes or volumes that collect judgments in the field of trade and census.

In Sicily, then, published examples of such literature are not found before 1593, but in the fifty years from 1600 to 1650 there are more than even thirty editions, which then diminish to less than ten in the second fifty years of the seventeenth century. The reasons behind that flourishing in this period are attributable to a number of factors. First, the stabilization process of the High Courts in Sicily, which began in the midfifteenth century matures with the prammatica de reformatione tribunalium of Philip II in November 1569. ${ }^{14}$ And 'with that decision, in fact, the structure of the judiciary of the island with the apex courts of the Regia Gran Corte end of the Concistoro della Sacra Regia Coscienza is essentially defined, including in relation to a preconceived system of ordinary appeals. $^{15}$

Added to this is surely the massive professionalization of the judiciary because of the presence, as judges of the supreme courts, of the greatest jurists of the island, especially those which could not but help to increase the prestige of the decisions taken by those courts. These same judges are also the authors of the collections of these decisiones. Significant influence may also have been a "fashion" which took the form of a literary genre in those years, which largely succeed in Europe. . Do not underestimate the momentum which was finally derived from the creation and dissemination of printing works in Palermo, useful for decreasing the cost and facilitating the necessary contacts for the editions.

The collections of decisiones by Sicilian judges and jurists stand on the

\footnotetext{
${ }^{9}$ M. Muta, Decisiones novissimae Magnae Regiae Curiae supremisque magistratus Regni Siciliae, Panormi 1619.

${ }^{10}$ O. Caracciolo, Decisiones Curiae Pretoris Felicis Urbis Panormi, Panormi 1641.

${ }^{11}$ G. Basilicò, , Decisiones Magnae Regiae Curiae Regni Siciliae, Messanae 1669.

${ }^{12}$ On The Decisiones issued by the Regia Gran Corte see A. Romano, Le decisiones della Regia Gran Corte del Regno di Sicilia. Forma delle sentenze, registrazione, raccolte, in Case Law in the making. The Techniques and Methods of Judicial Records and Law Reports, vol.2: Documents, edited by A. Wijffels, Berlin 1997, pp.137-194.

${ }^{13}$ On this subject could see F. Di Chiara, Per un repertorio della dottrina giuridica di età moderna. Le Decisiones del Concistoro della Sacra Regia Coscienza del Regno di Sicilia, Palermo 2011 (on-line version on www.mediterranearicerchestoriche.it).

${ }^{14}$ Pragmaticarum regni Siciliae novissima collectio, Panormi 1637, tomo II, tit. I, pragm. unica, pp.1-7.

${ }^{15}$ On Modern Sicilian administration of justice see A. Baviera Albanese, L'ufficio di Consultore del Vicerè nel quadro delle riforme dell'organizzazione giudiziaria del secolo XVI in Sicilia, in "Rassegna degli Archivi di Stato", 1960; now in Ead., Scritti minori, Soveria Mannelli (CZ), 1992, pp.109-158 e di V. Sciuti Russi, Astrea in Sicilia. Il ministero togato nella società siciliana dei secoli XVI e XVII , Napoli 1983.; A. Romano, La Regia Gran Corte del Regno di Sicilia, in Case Law in the Making. The Techniques and Methods of Judicial Records and Law Reports, vol. 1, edited by A. Wijffels, Berlin 1997, pp. 111-161; for a period longer dating see B.Pasciuta, In regia curia civiliter convenire. Giustizia e città nella Sicilia tardomedievale, Torino 2003, pp. 41-68.
} 
crossroads of several legal traditions at the end of the 16th and beginning of the 17th century. They are anchored in the civil law or ius commune tradition, but their perspective is that of the Sicilian's Kingdom. As works written primarily by the standards of the ius commune literature, they reflect in many ways the "law of the books", but because their proclaimed emphasis is on the practice of the sicilian superior courts, they also reflect to some degree legal practice, or, as it is sometimes called, the "law in action".

These collections of case law although totally neglected by historians to date, undoubtedly constitute sources of knowledge of primary importance not only for the study of legal thought between the Sicilian XVI and XVII century, but also to investigate the contribution of the doctrine to the interpretation and effective formation of the positive law of the Kingdom of Sicily.

To complete the picture, always with regard to the production of doctrine, treaties explicitly on the procedure for forensic activity are also held in high esteem, in addition to the collections of Decisiones. This is also the case for the 'practicae' and commentaries on the civil and criminal Ritus Magnae Regiae Curiae ${ }^{16}$ in particular, the source of law with which Alfonso V in 1446 intended to regulate the internal praxis of the courts of the Kingdom. ${ }^{17}$ These works, which were produced in considerable numbers as early as the second half of the fifteenth century, spread particularly in the late sixteenth and early seventeenth century, in the same period in which, as has been seen, the collections of sicilian decisiones also thrive. Also the authors of these works are all successful judges and lawyers, who often write not only treated but also collections of decisions. This factor determines not only homogeneity, especially in style between the two genres, but also a dense series of reciprocal citations among the decisiones and treaties in a continuous exchange between auctoritates that "play" to legitimize each other. This created a framework to render this dynamic and vibrant island of doctrine, which was compact at the same time and characterized by the intrinsic continuity which arose out of contamination between the genres.

Works of doctrine, despite their undeniable differences, mainly due to the different literary genres used by the authors, are characterized, in fact, for the purpose of explaining, and perhaps most importantly, for interpreting the Ritus, an interpretation that necessarily become creative, arise sufficiently to make the work of teaching a source which takes precedence over the original legal text. This finding seems incontrovertible, even with regard to the perception that users have the same law. In fact, all citations of the Ritus, contained in the collections of sicilian-decisiones which in the eyes of contemporaries reflected the law as applied in judicial practice, do not make direct reference to Ritus, but to the works in which this law is commented on, particularly in the two commentaries of Conversano ${ }^{18}$ and Cumia. ${ }^{19}$ So that which goes

\footnotetext{
16 The full text of the Ritus Magnae Regiae Curiae et totius Regni Siciliae Curiarum, by Alfonso V il Magnanimo is in Capitula regni Siciliae, edited by F. Testa, tt. II, Panormi 1741 (riprint edited by A. Romano, Saveria Mannelli (CZ) 1999), t. I pp. 240-273.

${ }_{17}^{17}$ On the Ritus Magnae Regiae Curiae see B. Pasciuta, In regia curia, pp.88-91.

${ }^{18}$ M. Conversano, Commentaria super ritu regni Siciliae ... a Marcello Conversano collecta, Panormi 1614.
} 
to make up the communis opinio, resolving disputes, is not the source of law, since it is the interpretation which makes the doctrine. The legislation, as such, seen rather in terms of in its deterioration, is unclear and uncoordinated. Hence, this doctrine, with its rationality, corrects it, thus providing a procedural model which to some extent offered an alternative to that imposed directed by standardization.

Moreover, it is no coincidence that in the sicilian collectios of decisiones statute law -both domestic and foreign- is occasionally, but not frequently, quoted as an authority. Indeed, case law essued by Sicilian or foreign courts appears to be by far the most frequently quoted type of authority, together with the works of doctrine, used as solutio to resolve disputes.

This is a response within the scope of the activity of lawyers, regarding the interpretation and implementation of the law, against the attempt by the sicilian monarchy to include procedural matters entirely within the legislative powers of the sovereign.

The formal law of the state and legal doctrine are therefore constantly engaged in a silent opposition to electing procedure as an arena for activities and accommodation, with the purpose stated, to bring order to a discipline which in itself is chaotic and less inclined to fall into grids which are unique and preconceived. ${ }^{20}$ Simply study the possible krasis of the rule laid down by the king and the interpretation given by lawyers in order to identify the space occupied by the law actually applied in the Kingdom.

Here, then, as the Sixteenth century judge, in his role as high royal official and at the same time as jurist author of works of doctrine, becomes the balance of the political, institutional an doctrinal reality of the Regnum Siciliae. In this regard the collections of decisions, made by the judges become primary sources that return this image of a legal doctrine committed to provide such an extensive interpretation of the royal law as to result almost subversive, presenting a scheme in wich the doctrin produced by the togati became itself a source of law, thus overtaking the royal legitimacy.

\footnotetext{
${ }^{19} \mathrm{G}$. Cumia, In ritus magnae regiae curiae ac totius regni Siciliae curiarum Commentaria, praxisque super eiusdem Magnae Regiae Curiae ritibus [....], Panormi 1578.

${ }^{20}$ This theme is further developed by B. Pasciuta, Le fonti giudiziarie del Regno di Sicilia tra tardo Medioevo e prima Età Moderna: le magistrature centrali, in La documentazione degli organi giudiziari nell'Italia Tardo-Medievale e Moderna, edited by A.Giorgi, S. Moscadelli and C. Zarrilli, Siena 2012, pp. 315-330.
} 